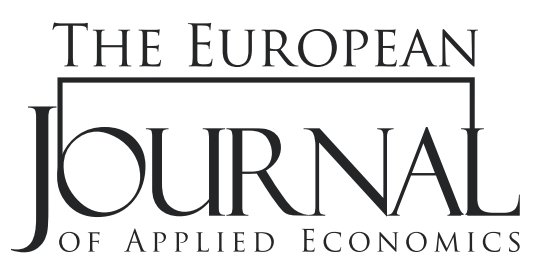

\title{
THE INFLUENCE OF DEMOGRAPHIC CHARACTERISTICS OF CONSUMERS ON DECISIONS TO PURCHASE TECHNICAL PRODUCTS
}

\author{
Adis Puška1,*, Ilija Stojanović ${ }^{2}$, Sead Šadić ${ }^{3}$, Haris Bečić ${ }^{4}$ \\ ${ }^{1}$ Independent researcher, \\ Brcko, Bosnia and Herzegovina \\ ${ }^{2}$ European University Brcko District, \\ Brcko, Bosnia and Herzegovina \\ ${ }^{3} \mathrm{PHI}$ Health Center Brcko, Spokesman, \\ Brcko, Bosnia and Herzegovina, \\ ${ }^{4}$ College of eMPIRICA, \\ Brcko, Bosnia and Herzegovina
}

\begin{abstract}
:
The term consumer behavior has become very popular in recent studies. It is characterized by various processes, with consumers purchasing decisions being one of them. This paper explores the way in which demographic characteristics influence purchasing decisions with focus on technical products including household appliances, computers, TV sets and similar technical products that cost more than 400 BAM. The empirical study was conducted in the region of northeast of Bosnia Herzegovina and 192 respondents were included in the study to express their allegations of purchasing decisions. Factor analysis was used to identify broader constructors as a basis for observation of the variables. In total, six variables were identified. Based on the calculation of Cronbach's Alpha indicators, it has been established that there was a low internal affiliation of claims in two variables, upon what they were discarded. Thus, four variables were used to study purchasing decision-making. The results of multivariate analysis of variance (MANOVA) showed that gender, income level and employment status of the respondents significantly influence purchasing decisions among consumers. The analysis of variance (ANOVA) has further shown that females Under the age of 25 and whose income is less than 400 BAM with less than 25 years are generally dedicating to purchasing decisions. The empirical findings showed that the most satisfied with their purchasing decisions are male respondents, whose income varies between 400 BAM and 800 BAM and who belong to the category of students under 25 years.
\end{abstract}

Article info:

Received: April 14, 2018

Correction: May 5, 2018

Accepted: May 9, 2018

\section{Keywords:}

consumer behavior, buying decisions, demographic factors, factor analysis, multivariate analysis of variance, analysis of variance. 


\section{INTRODUCTION}

Nowadays more focus is being given to study the importance of consumer behavior in marketing. The business environment is increasingly changing and it is very difficult for companies to fight for customer and market share (Khaniwale, 2014). Each company must adapt to changes in the market to survive. Companies must be familiar with their customers' needs and their purchasing decisions.

Consumer behavior is a complex process that involves a variety of activities including: search, selection, purchase, use, evaluation of products and services to meet their needs and desires (Belch \& Belch, 2004). Several internal and external factors, which can range from short-term to long-term emotional feelings, are affecting customer behavior (Hirschman, 1985). Marketing experts need to understand the dynamics of internal factors that are influencing consumers' decisions. These factors vary from person to person, from situation to situation; therefore, it is important to draw some generalizations of consumer behavior (Komal Prasad \& Jha, 2014).

Main decisions for the consumer are: what he buys (which products and services), how much (amount), where (place of purchase), the time spent shopping and payment methods (Khaniwale, 2014). This study is focused on purchasing decision with the focus on technical goods. The aim of this research is to find out how consumers behave and how they are deciding on buying technical equipment.

This research is focused on studying consumer purchasing decisions on the example of technical goods. This research has been conducted in order to find out which demographic factors have the greatest impact on consumer buying behavior and how they influence purchasing decision-making. Based on the results, understanding of customer behavior in purchasing decision-making will be improved which will assist the sellers of the technical devices to promote their products in order to make more impact on purchasing decisions as a most important segment in buying process. In this paper, beside the introduction section, the theoretical framework will be provided and hypotheses of research will be set up in the second part of the paper, research methodology will be given in the third part, the results will be processed and the discussions will be conducted in the fourth part, and finally, the most important conclusions from the research will be given in the fifth part.

\section{LITERATURE REVIEW}

Consumer behavior includes an analysis of individuals by understanding which method they use to select products, and how they use products and services to fulfill their desires. Consumer behavior refers to all thoughts, feelings and actions that the individual has or had before or during purchasing of the product, service or idea. Main activity in studies of consumer behavior is to understand the process of purchasing decision. The whole process of purchase decision making involves a consideration what to buy, what brand is good or appropriate, where to shop from and when, how much time to spend and at what intervals. Therefore, the end result of customer behavior is making a final decision on the product choice, brand choice, choice of retailers, purchase time, purchase amount and frequency of purchase (Khaniwale, 2014).

Demographic, behavioral and psychographic factors help to understand consumers and their needs (Kotler \& Armstrong, 2007). In marketing surveys demographic factors such as age, number of household members, sex, income level and social class are used extensively, and are considered as 
good indicators for the study of consumer behavior (Iqbal, Ghafoor \& Shahbaz, 2013). Behavioral factors refer as a way how consumer behaves, how they accept certain products, why they accept it, etc. Psychographic factors are used for determining and evaluating the lifestyle of consumers, the ways they use their activities, interests and opinions (Tam \& Tai, 1998). The study is particularly focused on demographic characteristics of respondents.

When deciding on purchase of various products the consumers make various efforts. The least effort is invested in purchase of food products, because decision on purchasing these products is done automatically and without much thinking. When buying certain products like cars and some technical equipment, the purchase is preceded by a long deciding and consideration of various options to make the final purchasing decision (Markovina, Kovačić \& Radman, 2004). Decisions that require a strategic approach are very specific and they are characterized by: high involvement in decision-making, longterm resources acquiring budget available for the purchase of other goods and services (Kos Koklič \& Vida, 2009). Sometimes the purchase of technical equipment requires major efforts in the decisionmaking process.

The level of decision making, which comes before the purchase, is a very important factor in marketing research. Based on the obtained data about the level and complexity of decision making for individual product, it is possible to conduct market segmentation and determination of the targeted market where each company will operate. During market segmentation consumers can be divided according to the degree of involvement in the process into the consumers of high, medium and low involvement. Using that approach, it is possible to create marketing messages to targeted consumers that will have the greatest impact on purchasing decision. Also, the data on the involvement of consumers may be used to customize products. Previous studies have shown different behaviors of consumers when purchasing depending on their involvement (Beatty \& Smith, 1987).

The purchase decision-making process that a consumer goes through includes the following phases (Engel \& Blackwell, 1978):

- recognition of the problem,

- search for information,

- estimating alternatives,

- purchasing decision and

- behavior after the purchase.

The first phase begins with the need or the recognition of the problem. This is followed by a search for alternatives that include seeking information from various sources, as well as internal and external environment, such as experience. The third phase involves consumer criteria in calculating benefits subjected to evaluating alternatives. When a decision is made, the consumer enters the fourth phase where the purchase of selected alternatives takes place. The final step involves post-purchase evaluation and consumer behavior after the purchase (SueLin, 2010). The assessment of experience may be influenced by time-dependent parameters that do not have to be directly related to the service, but will lead to an accumulation of experience using this product or service (Dulleck \& Kerschbamer, 2006). In recent years, for many reasons, the value of user experience appears to be an important issue in marketing research. Creating experiential value is crucial for customer satisfaction and loyalty (Echchakoui, 2016). In the service, sector customer experience helps retail environments to create a sustainable competitive position (Srivastava \& Kaul, 2014). 
Many factors influence consumer's purchasing decision making. Demographic factors play an important role in purchasing process. Income, age, occupation, and other demographic factors may influence decision-making (Anderson \& Gaile-Sarkane, 2008). Iqbal Ghafoor \& Shahbaz (2013) showed in their study that the following demographic factors influence the selection of shops to purchase goods: the level of education, occupation, income level, number of household members. Sharma \& Kaur (2015) proved in their study that sex and marital status significantly affect the way of purchasing. Alooma \& Lawan (2013) showed that demographic factors, such as age, sex, marital status, occupation, education and income, are key variables that influence consumer behavior. Mazloumi et al. (2013) demonstrated that gender, education, marital status, activity and age play an important role in the buying behavior of consumers. A large number of studies have examined individual values, personal attitudes, ethnicity, normative pressure and cognitive bases, including functional background and educational qualifications, as well as their impact on purchase (Mansi \& Pandey, 2016). Based on this, demographic characteristics, social and individual values and personal attitudes affect individuals in their purchasing decisions.

Multidisciplinary research worksconcluded that there are gender differences in purchasing behavior and socially responsible behavior (Homburg \& Giering, 2001). Studies have shown that women are prone to impulsive shopping and are more loyal to brands (Tifferet \& Herstein, 2012) and therefore more and more retailers turn to women as a target group. In some studies, the female sample is more likely to adopt environmentally-friendly purchasing practices (Mainieri et al. 1997; Liu et al. 2012). The following hypothesis is based on previous conclusions:

- $\mathrm{H}_{1}$ - There is a significant difference in the purchasing decision-making with regard to gender

As the income level determines consumers' purchasing power, consumers with high-income can afford to buy real estate, life insurance policies, expensive cars, travels, etc. In contrast, low-income consumers will be satisfied with basic living needs and choose affordable products (Štulec et al. 2017). Professionals influence socially responsible purchasing, and in particular the qualifications and competences of procurement experts probably have a strong impact on environmental, safety and philanthropic activities (Kacprzak \& Pawłowska, 2017). Based on this, the following hypothesis was set:

- $\mathrm{H}_{2}$ - There is a significant statistical difference in the purchasing decision making with regard to the amount of household income

Research has shown that there is a difference in customer behavior depending on their qualifications (Chan, 1996). Hambrick and Mason (1984) claim that the educational background is a useful indicator of knowledge and skills. The meta-analysis carried out by Hines, et al. (1987) state that there is a difference in behavior between highly educated and less educated individuals. In contrast, Olli, et al. (2001), does not find such significant differences between highly educated and less educated individuals. The conclusion is that the level of education is positively linked to the acceptability of innovation (Kimberly \& Evanisko, 1981) which tells us about customer acceptability of some new technologies. Based on this, the following hypothesis was set:

- $\mathrm{H}_{3}$ - There is a significant statistical difference in the purchasing decision-making with regard to consumer's level of education

The current status of respondents plays a major role on their income. Unemployed respondents have lower income levels and they will find purchasing decision making more important and select products that have lower prices (Štulec et al. 2017). It is, therefore, important to recognize how the status of respondents affects purchasing decisions, whether employees pay less attention to buying decisions from unemployed people and how they decide. Based on this, the following hypothesis was set: 
- $\mathrm{H}_{4}$ - There is a significant statistical difference in the purchasing decision-making with regard to consumer's employment status

Studies have shown that age has impact in relation to sustainable purchasing and environmental intentions (Anderson \& Cunningham, 1972; Samdahl \& Robertson, 1989). According to Carlsson and Karlsson (1970), people with different age enable different responsiveness to the force called "stimulatory pressure" having in mind that younger people are changing faster than older people. Previous studies (Parment, 2013; Kacprzak \& Pawłowska, 2017) have shown that younger generations can handle a large amount of information easier. Based on this, the following hypothesis was set:

- $\mathrm{H}_{5}$ - There is a significant statistical difference in the purchasing decision-making with regard to consumer age

Family as a spending unit is often the most interesting to marketing experts due to the greatest spending and the role of a woman in the family who often makes the purchasing decision. Nordstroem and Ridderstrale (2002) say that things have become very personal and that freedom of choice has become a key element in the present time. Children, both young and teenagers, can have a significant impact on the budget allocation and purchasing decisions. Childbirth is also a major event that creates the need for a new and wide range of products that future parents were not buying before (Peter, 2005). In accordance with the abovementioned information, the following hypothesis on household members is formed:

- $\mathrm{H}_{6}$ - There is a significant statistical difference in the purchasing decision-making with regard to the number of household members among consumers

\section{METHODOLOGY}

The empirical study was conducted in the region of northeast of Bosnia Herzegovina during 2016 in the period from January to May. The aim of this study was to examine how consumers make their purchasing decisions when buying technical products. Convenience sample was used for data collection. An online questionnaire placed on the scientific portal 1ka.si, that is promoted trough Facebook pages of the largest portals in the region, has been used. In total, 2,084 respondents accessed the online questionnaire, and 192 respondents completed the questionnaire, which represents a response rate of $9.21 \%$.

The questionnaire consisted of two parts. The first part contained general questions about demographic characteristics of respondents: sex, household income, education, employment status, age and number of household members. The second part of the questionnaire contained 21 statements which used the Likert scale of 5 levels interval from "strongly disagree" to "strongly agree". The claims used in this group of questions are adapted from the following studies: Beatty \& Smith (1987), Jeyakumar \& Paul Robert (2010), Bui, Krishen and Bates (2011) and Waheed, Mahasan \& Sandhu (2014). Based on these studies the claims for consumer behavior during purchase of technical equipment was adjusted. Statistical analysis of the data obtained in this study was performed using the SPSS 20 software tool.

In this the work following steps have been used:

1. Presentation of the demographic characteristics of the respondents,

2. grouping claims using factor analysis, and testing reliability of the measurement scale of collected the data, 
3. testing hypotheses using multivariate analysis of variance(MANOVA), and

4. analysis of the influence of certain demographic characteristics of the respondents in purchasing decisions via analysis of variance (ANOVA).

In order to examine the results, the factor analysis indicators of Kaiser-Meyer-Olkin's (KMO) adequacy of the sample and Bartlett's test of sphericity were used. The KMO value ranges in closed interval from zero to one. If its value is less than 0.6, than the correlation matrix is not acceptable for factor analysis. In Bartlett's test, it is preferred that the level of significance is less than $\mathrm{p}<0.05$ (Puška, Maksimović \& Fazlić, 2015). During the implementation of factor analysis varimax rotation of factors and Kaiser Normalization was used. Reliability of the scale of collected data was tested using Cronbach's alpha coefficient whose results range from zero to one. If the value of this indicator is close to zero, then these data are unreliable, and if they are close to one then they are very reliable (Kozarević \& Puška, 2015). In order to accept some factors, it is necessary that the value of Cronbach's alpha is higher than 0.7 (Tavakol \& Dennick, 2011).

MANOVA and ANOVA were used. These analyzes are used to answer the question: Do the changes in the independent variables have significant effects on change in the dependent variables (Grbić \& Puška 2015)? While conducting these analyzes it was examined how the demographic characteristics of respondents influence purchasing decisions when buying technical products.

The research hypotheses testing was conducted at the level of inferential statistics of 0,05 ( $p<0,05)$, which means that if the significance level is lower than the set level the null hypothesis is accepted, otherwise the alternative hypothesis is accepted and the null hypothesis is rejected.

\section{RESULTS AND DISCUSSION}

Our first step is to analyze the basic characteristics of the respondents included in the study that is showed in Table 1.

\begin{tabular}{llcc}
\hline & Demographic variables & Frequency & Percentage \\
\hline \multirow{2}{*}{ Sex } & 1. Male & 118 & $61.5 \%$ \\
& 2. Female & 74 & $38.5 \%$ \\
\hline \multirow{3}{*}{ Household income in BAM } & 1. Less then and equals to 400 & 25 & $13,2 \%$ \\
& 2. $401-800$ & 57 & $30.0 \%$ \\
& 3. $801-1200$ & 44 & $23,2 \%$ \\
& 4. More than 1201 & 64 & $33.7 \%$ \\
\hline \multirow{3}{*}{ Level of education: } & 1. Primary education & 6 & $3.1 \%$ \\
& 2. Secondary Education & 86 & $44.8 \%$ \\
& 3. Higher education & 32 & $16.7 \%$ \\
Employment status: & 4. University degree & 68 & $35.4 \%$ \\
\hline & 1. Student & 53 & $28.0 \%$ \\
& 2. Employed & 99 & $52.4 \%$ \\
\hline
\end{tabular}




\begin{tabular}{llcc}
\hline & $1.15-24$ & 64 & $33.3 \%$ \\
Age: & $2.25-40$ & 103 & $53.6 \%$ \\
& $3.41-54$ & 22 & $11.5 \%$ \\
& 4.55 and more & 3 & $1.6 \%$ \\
\hline \multirow{3}{*}{ Number of household members: } & $1.1-2$ & 40 & $21.5 \%$ \\
& $2.3-4$ & 106 & $57.0 \%$ \\
& $3.5-6$ & 43 & $18.3 \%$ \\
& 4.7 and more & 6 & $3.2 \%$ \\
\hline
\end{tabular}

Table 1. The results of demographic characteristics of the respondents

Out of a total number of 192 respondents, $61.5 \%$ of respondents are males, while $38.5 \%$ are females. Observing the household income of respondents, most of them have a monthly household income of more than 1200 BAM which is $33.7 \%$ of the respondents, followed by the respondents with a monthly household income between 401 and 800 BAM which is 30.0\%, followed by respondents having a monthly household income between 801 and 1200 BAM 23.3\%. The last group of respondents have a monthly household income of less than 400BAM 13.2\%.

In relation to the educational structure, most of the respondents possess a high school education with $44.8 \%$, followed by the respondents who have a university degree with $35.4 \%$, then the respondents with higher education with $16.7 \%$, while the least respondents possesses a lower level of education who are represented with $3.1 \%$. Observing the employment status of respondents, the most of respondents are employed with $52.1 \%$ followed by students with $27.9 \%$, and unemployed persons with $19.5 \%$.

In our sample, most of the respondents are aged between 25 and 40 years, with 53.6\%, then the respondents aged between 15 and 24 years with $33.3 \%$, followed by respondents between 41 and 54 years of age with $11.5 \%$, while the least respondents have more than 55 years with $1.6 \%$. Most respondents belong to a household with 3 or 4 members representing $57.0 \%$ of the sample, followed by those who have one or two members in the household with $21.5 \%$, and then followed by respondents who have 5 or 6 members in a household with $18.3 \%$, while the least respondents have 7 or more members of the household with $3.2 \%$ in the sample.

After presenting the basic demographic characteristics of the respondents, the next analysis indicates whether the collected data are acceptable for further analysis. By using factor analysis, whose results are presented in Table 2, specific grouping statements were analyzed. Apart from this analysis, the table contains calculated values of Cronbach's Alpha indicators that will be used to determine the reliability of measurement scales of the collected data.

The results were obtained by performing factor analysis and are shown in Figure 1. As shown from Figure 1, six factors have an eigenvalue greater than one. Thus, based on the Kajzer criterion, the factor analysis has grouped used claims into six factors. Table 2 shows values of the factor coefficients for each factor and the amount of individual variance factors used for explanation. 


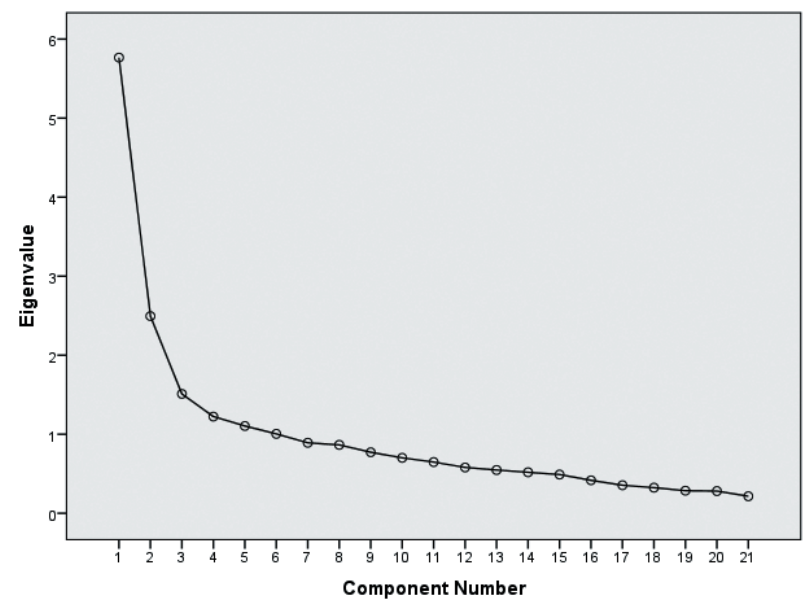

Figure 1. Scree plot

\begin{tabular}{|c|c|c|c|c|c|c|}
\hline & \multicolumn{6}{|c|}{ Factor } \\
\hline & 1 & 2 & 3 & 4 & 5 & 6 \\
\hline I accept tips given to me by salesperson & .74 & & & & & \\
\hline When I cannot decide what to buy I ask salesperson & .74 & & & & & \\
\hline I ask salesperson for additional information & .72 & & & & & \\
\hline Salesperson plays a significant role in purchase of technical products & .68 & & & & & \\
\hline I am looking for alternatives by visiting various shops & .56 & & & & & \\
\hline \multicolumn{7}{|c|}{ Factor 1. Role of salesperson in purchasing process, explained variance $=27.46$, Cronbach's alpha $=.76$} \\
\hline $\begin{array}{l}\text { All hard work that I put in process of deciding on purchase of tech- } \\
\text { nical products has paid off }\end{array}$ & & .78 & & & & \\
\hline When I buy a device, I feel very satisfied & & .78 & & & & \\
\hline $\begin{array}{l}\text { After purchasing I do not feel guilty conscience that I could buy } \\
\text { another product }\end{array}$ & & .69 & & & & \\
\hline I'm confident in my decision and I am not changing it & & .60 & & & & \\
\hline \multicolumn{7}{|c|}{ Factor 2. Satisfaction with purchasing decision, explained variance $=11.88$, Cronbach's alpha $=.75$} \\
\hline $\begin{array}{l}\text { I ask my friends and acquaintances for help when buying technical } \\
\text { products }\end{array}$ & & & .66 & & & \\
\hline I am looking for alternatives on the Internet & & & .62 & & & \\
\hline $\begin{array}{l}\text { It takes me days to decide on } \\
\text { purchase of technical products }\end{array}$ & & & .56 & & & \\
\hline When I collect all possible alternatives I make decision at home & & & .52 & & & \\
\hline \multicolumn{7}{|c|}{ Factor 3. Shopping information, explained variance $=7.19$, Cronbach's alpha $=.70$} \\
\hline I make decisions on purchase of technical products at home & & & & .77 & & \\
\hline $\begin{array}{l}\text { Usually I am not making decisions to purchase technical products } \\
\text { on my own }\end{array}$ & & & & .74 & & \\
\hline
\end{tabular}


I am buying a new technical product only when old one is broken or is outdated

Factor 4. Decision to purchase, explained variance $=5.83$, Cronbach's alpha $=.73$

I have shopping only at certain stores where I have had positive experiences from past purchases

.76

When buying technical products I buy trusted brands .55

When shopping I know exactly which product I will buy .51

Factor 5. Previous experience, explained variance $=5.26$, Cronbach's alpha $=.65$

Price plays a key role in purchase of technical products .78

Warranty length has a very important role in purchasing of technical products

Factor 6. Price and warranty, explained variance $=4.79$, Cronbach's alpha $=.49$

$\mathrm{KMO}=.800, \chi^{2}=1077.79$, Bartlett's Test of Sphericity $=.00$, explained variance $=62.40$

Table 2. Factor analysis of data acceptability

The results of the factor analysis (Table 2) grouped the claims into six factors. These factors explained $62.40 \%$ of the variance of the basic set which is a customary percentage that is present in social research (Kurnoga Živadinović, 2004). The value of the KMO indicator is higher than the required 0.6 (KMO = $.80)$, while the value of Bartlett's test is lower than the set level of significance $(\mathrm{p}=.00)$, which confirms the results of the factor analysis.

The first factor,indicated as "Role of salesperson in purchase process", explains $27.46 \%$ of the variance. This factor grouped the five statements that are mostly related to the role of salesperson in making purchasing decisions. The value of Cronbach alpha indicator is greater than 0.7 (.76), thus confirming the reliability of the scale of collected data for this factor. The second factor, indicated as "Satisfaction with purchasing decision", included the four statements related to satisfaction of the respondents with their decision with purchase of technical equipment. This factor explains $11.88 \%$ of the variance of the basic set. The results of Cronbach's alpha for this factor are greater than 0.7 (.74) which confirms that the collected data are reliable for further analysis. The third factor, indicated as "Shopping information", included the four statements that are related to the way of looking for alternatives by the respondents. This factor explains 7.19\% of the variance of the basic set. The value of Cronbach's alpha is very close to the set level of confidence (.70). Thus, the data that are grouped by this factor are reliable and acceptable for further analysis. The fourth factor, indicated as "Purchase decision", included the three claims that are related to the way in which the respondents decide about the purchase of technical equipment. This factor explains 5.83\% of the variance of the basic set and the resulting value of Cronbach's alpha indicators is higher than the set level of reliability (.73) which proves that the data grouped by this factor are reliable for further analysis.

The fifth factor, indicated as "Previous experience", grouped the three claims related to previous experience with the shop or device that has a positive impact on the purchasing decision. This factor explains $5.26 \%$ of the variance of the basic set, and the value of Cronbach's alpha for this factor is low (.65). Having in mind this result, the conclusion is that the data grouped by this factor are unreliable for further 
analysis. This value of Cronbach's alfa could be caused by a small number of questions, weak correlation between the questions or heterogenic questions. The sixth factor, indicated as "Price and warranty", included the two items related to the impact of price and product warranty on the purchasing decision. This factor explains $4.79 \%$ of the variance of the basic set and the value of Cronbach's alpha is very low for this factor (.49). It is concluded that the data are unreliable and will not be used for further analysis.

The results of the factor analysis have reduced the total number of claims from 21 to 16 that are grouped into four factor groups. In the further analysis only the first four factors will be used because they have a reliable measurement scale, while the last two factors are discarded from further analysis. Furthermore, MANOVA analysis was used to examine the hypotheses identified in this study.

\begin{tabular}{lccc}
\hline \multicolumn{1}{r}{ Respondents' characteristics } & F-test & Sig. & Status of hypothesis \\
\hline Sex & $\mathbf{5 . 1 7}$ & $\mathbf{. 0 0 1}$ & Accepted \\
\hline Household income & $\mathbf{1 . 9 7}$ & $\mathbf{. 0 2 5}$ & Accepted \\
\hline Level of education & .99 & .462 & Discarded \\
\hline Employment status & $\mathbf{2 . 3 4}$ & $\mathbf{. 0 1 8}$ & Accepted \\
\hline Age & 1.05 & .403 & Discarded \\
\hline Number of household members & 1.13 & .336 & Discarded \\
\hline
\end{tabular}

Table 3. Testing the hypothesis using MANOVA analysis

The results of MANOVA analysis are shown in Table 3. According to the empirical findings, three hypotheses are accepted, and three hypotheses are not accepted. This analysis showed that gender $(\mathrm{F}=$ $5.17, \mathrm{p}=.001)$, household income $(\mathrm{F}=1.97, \mathrm{p}=.025)$ and employment status $(\mathrm{F}=2.340, \mathrm{p}=.018)$ play an important role in purchasing decisions of the respondents. However, this analysis showed that the level of education $(\mathrm{F}=.99, \mathrm{p}=.462)$, age $(\mathrm{F}=1.05, \mathrm{p}=.403)$ and the number of household members ( $\mathrm{F}$ $=1.13, \mathrm{p}=.336$ ) do not play a significant role in purchasing decisions among the respondents included in this study, since there are no statistically significant indicators to claim the opposite.

After testing the hypothesis with MANOVA, an ANOVA analysis was conducted to examine the impact of certain factors within the individual characteristics of the respondents to determine what factors our respondents use when deciding about the purchase of technical equipment.

\begin{tabular}{llcccc}
\hline \multirow{2}{*}{$\begin{array}{l}\text { Respondents' } \\
\text { characteristics }\end{array}$} & \multicolumn{1}{c}{ Factor } & Variance & F-test & Sig. & Ratio \\
\hline \multirow{4}{*}{ Sex } & Role of the salesperson in purchasing process & $\mathbf{4 . 5 5}$ & 7.47 & .007 & $\mathbf{1}<\mathbf{2}$ \\
\cline { 2 - 6 } & Satisfaction with purchasing decision & .95 & 1.50 & .223 & $2<1$ \\
\cline { 2 - 6 } & Shopping information & .35 & .53 & .467 & $1<2$ \\
\cline { 2 - 6 } & Decision to purchase & $\mathbf{7 . 5 0}$ & $\mathbf{8 . 7 0}$ & $\mathbf{. 0 0 4}$ & $\mathbf{1}<\mathbf{2}$ \\
\hline \multirow{3}{*}{$\begin{array}{l}\text { Household } \\
\text { income }\end{array}$} & Role of salesperson in purchasing process & $\mathbf{2 . 2 8}$ & $\mathbf{3 . 7 8}$ & $\mathbf{. 0 1 2}$ & $\mathbf{3}<\mathbf{4}<\mathbf{2}<\mathbf{1}$ \\
\cline { 2 - 6 } & Satisfaction with purchasing decision & .18 & .28 & .838 & $3<1<4<2$ \\
\cline { 2 - 6 } & Shopping information & 1.67 & 2.60 & .054 & $2<3<4<1$ \\
\cline { 2 - 6 } & Decision to purchase & $\mathbf{2 . 3 9}$ & $\mathbf{2 . 7 2}$ & $\mathbf{. 0 4 6}$ & $\mathbf{2}<<<\mathbf{3}<\mathbf{1}$ \\
\hline
\end{tabular}




\begin{tabular}{|c|c|c|c|c|c|}
\hline \multirow{4}{*}{$\begin{array}{l}\text { Level of } \\
\text { education }\end{array}$} & Role of salesperson in purchasing process & .85 & 1.36 & .257 & $4<2<3<1$ \\
\hline & Satisfaction with purchasing decision & .20 & .32 & .811 & $2<4<3<1$ \\
\hline & Shopping information & 1.02 & 1.58 & .196 & $3<2<4<1$ \\
\hline & Decision to purchase & 1.46 & 1.64 & .181 & $4<3<2<1$ \\
\hline \multirow{4}{*}{$\begin{array}{l}\text { Employment } \\
\text { status }\end{array}$} & Role of salesperson in purchasing process & .27 & .43 & .651 & $3<1<2$ \\
\hline & Satisfaction with purchasing decision & 2.28 & 3.78 & .025 & $3<2<1$ \\
\hline & Shopping information & .83 & 1.32 & .271 & $2<3<1$ \\
\hline & Decision to purchase & 3.45 & 4.04 & .019 & $2<3<1$ \\
\hline \multirow{4}{*}{ Age } & Role of salesperson in purchasing process & 1.05 & 1.69 & .171 & $4<2<3<1$ \\
\hline & Satisfaction with purchasing decision & .64 & 1.00 & .392 & $3<2<1<4$ \\
\hline & Shopping information & .27 & .40 & .750 & $3<2<4<1$ \\
\hline & Decision to purchase & 2.20 & 2.51 & .060 & $2<3<1<4$ \\
\hline \multirow{4}{*}{$\begin{array}{l}\text { Number of } \\
\text { household } \\
\text { members }\end{array}$} & Role of salesperson in purchasing process & .42 & .68 & .564 & $3<4<2<1$ \\
\hline & Satisfaction with purchasing decision & .79 & 1.27 & .285 & $4<1<2<3$ \\
\hline & Shopping information & 1.25 & 2.01 & .115 & $4<2<3<1$ \\
\hline & Decision to purchase & .78 & .89 & .447 & $4<2<1<3$ \\
\hline
\end{tabular}

Table 4. Factor dependency on basic characteristics of the respondents

The results of the ANOVA analysis (Table 4) for "gender" as one of the basic characteristic of the respondents has shown that there is a significant statistical difference between the two factors: "Role of salesperson in purchasing process" $(\mathrm{F}=7.47, \mathrm{p}=.007)$ and "Decision of purchase" $(\mathrm{F}=8.70, \mathrm{p}=$ .004), while in the other two factors there is no significant difference.

The ratio represents the arithmetic mean of the offered answers for certain dimensions for the basic characteristics, which is in this case "gender". These relationships between factors showed that female respondents have consulted more salespersons, have looked for more alternatives, and got along with more statements when making decisions on purchase of technical goods, while male respondents were more satisfied with their purchase decision.

For the basic characteristic "household income", the results have shown that there is a significant statistical difference for the factors: "Role of salesperson in purchasing process" $(\mathrm{F}=3.77, \mathrm{p}=.012)$ and the "Decision to purchase" $(\mathrm{F}=2.72, \mathrm{p}=.046)$. For other factors, there is no significant difference in the answers. The ratio indicated that the statements related to buying decision are mostly used by the respondents with a monthly household income below 400 BAM, while the second place was taken by the respondents with income rates higher than 1200 BAM. These findings suggest that the household income does not play a decisive role in the purchasing decision because the respondents who have income levels between 400 and 1200 BAM are the least satisfied with their purchasing decisions since they also use purchasing decisions the least.

The results related to the level of education of the respondents indicated that there is no significant statistical difference in the answers for any of the factors. What is the characteristic about these findings is that purchasing decision is most used by those respondents who have lower levels of education, while the order in other dimensions ranges differently in comparison to other factors. It has been found that those respondents with a university degree are least satisfied with their purchasing decision, the 
respondents with higher education contact salespersons least and do not make decisions to purchase at home, while respondents with higher education look for alternatives in the form of technical goods the least in relation to the other.

Using the basic characteristic „Employment status of the respondents“, it has been found that there is a statistically significant difference for the following factors: "Satisfaction with purchasing decision" $(\mathrm{F}=3.78, \mathrm{p}=.025)$ and "Decision to purchase" $(\mathrm{F}=4.04, \mathrm{p}=.019)$, while the other factors do not have significant differences in the answers. The results of the relationships indicated that students are most satisfied with purchasing decisions, they are looking for alternatives the most and make decisions at home, while employed people contact salespersons the most. Furthermore, unemployed persons contact salespersons the least. They are least satisfied with their buying decision, while employed respondents look for alternatives the least and do not make decisions to purchase at home.

The results for the primary characteristic „Respondents age” have shown that there is no significant difference in any of the factors. The respondents who have less than 25 years contact salespersons the most and look for alternatives, while the most satisfied with the decision are the respondents who have more than 55 years. The findings should be taken with some caution because there were only three respondents with more than 55 years. The respondents aged between 41 and 55 years are least satisfied with purchasing decision, and look for alternatives the least, while respondents aged between 25 and 40 years make decisions to purchase at home the least.

After a closer look at the results for the basic characteristic „Number of household members” ,it has been found that there is no significant difference for any of the factors. Thus, the number of household members does not particularly effect the purchasing decision. Moreover, it has been found that the respondents who have one or two household members use salesperson opinion most, while the respondents who have five or six household members are the most satisfied with their purchasing decision. The respondents with seven or more household members use purchasing decisions the least.

\section{CONCLUSION}

The results of MANOVA analysis have shown that there is a significant statistical difference for the following basic demographic characteristics including gender, income level and status of the respondents thus playing a significant role in purchasing decisions. Three hypotheses are proven in this study indicating that the following basic characteristics of the respondents are significant: sex, household income and employment status. The other three hypotheses are discarded because it is proven that there is no significant statistical difference in the following basic characteristics of the respondents: level of education, age and number of household members.

The importance of this research was to investigate how demographic characteristics of respondents in $\mathrm{B} \& \mathrm{H}$ influence purchasing decision making. The importance of research is reflected in the fact that $\mathrm{B} \& \mathrm{H}$ residents are at the bottom of the European scale when it comes to per capita income. Therefore, the obtained results are particularly important because they are about buying technical equipment that require significant amount of money. The obtained results will help manufacturers and retailers of technical goods understand the behavior of consumer in countries with small per capita income levels. This will allow them to adapt to any demand, regardless of the country they are located in. Therefore, it was important to conduct this research in $\mathrm{B} \& \mathrm{H}$. 
ANOVA proved that female respondents consult more salesperson, look for more alternatives, and decisions to purchase make at home. Male respondents are more satisfied with their own purchase decision. It has been proved that people with income less than 400 BAM and people with low level of education spend most of their time on purchasing decision. The empirical findings have shown that students are the most satisfied with purchasing decisions. They look for most alternatives and make decisions to purchase at home, while employees contact salespersons the most. It has been noticed that respondents who are younger than 25 years contact more salesperson, and look for more alternatives. Number of household members has no effect on purchasing decisions.

Based on these findings it can be concluded that females, who have income levels less than 400 BAM with lower level of education and less than 25 years, spend most of the time in searching for alternatives. People, who are male and have income levels higher than 800BAM, older than 55 years use purchasing decisions the least. The most satisfied with their purchasing decisions are male respondents, who have income levels between 400BAM and 800BAM and have a lower level of education.

This study has its limitations which can be resolved in future studies. The biggest drawback was the questionnaire since the claims about purchase decision-making were too similar. Thus, it was not possible to group the reliable data as shown in the results of Cronbach's Alpha. In future studies, it is necessary to include more subjects in research and to cover larger territories. Despite all these shortcomings, this paper represents one of the first papers that explore purchasing decisions in Bosnia and Herzegovina giving significant guidelines for future research in this area.

\section{REFERENCES}

Alooma, A.G., \& Lawan, L.A. (2013). Effects of Consumer Demographic Variables on Clothes Buying Behaviour in Borno State, Nigeria. International Journal of Basic and Applied Science, 1(4), 791-799.

Anderson, W.T., \& Cunningham, W.H. (1972). Gauging foreign product promotion. Journal of Advertising Research, 12(1), 29-34.

Andersone, I., \& Gaile-Sarkane, E. (2008). Influence of factors on consumer behavior. 5th International Scientific Conference (pp. 331-337). Vilnius: Technika.

Beatty, S.M., \& Smith, S.M. (1987). External Search Effort: An Investigation Across Several Product Categories. Journal of Consumer Research, 14(1), 83-95. DOI:10.1086/209095

Belch, G.E., \& Belch, M.A. (2004). Advertising and Promotion: An Integrated Marketing Communications Perspective. New York: McGraw Hill.

Bui, M., Krishen, A.S., \& Bates, K. (2011). Modeling regret effects on consumer post-purchase decisions. European Journal of Marketing, 45(7/8), 1068-1090. DOI:10.1108/03090561111137615

Carlsson, G., \& Karlsson, K. (1970). Age, cohorts and the generation of generations. American Sociological Review, 35(4), 710-718. DOI:10.2307/2093946

Chan, T. (1996). Concerns for environmental issues and consumer purchase preferences: a two-country study. Journal of International Consumer Marketing, 9(1), 43-55. DOI:10.1300/J046v09n01_04

Dulleck, U., \& Kerschbamer, R. (2006). On Doctors, Mechanics, and Computer Specialists: The Economics of Credence Goods. Journal of Economic Literature, 44(1), 5-42. DOI:10.1257/002205106776162717

Echchakoui, S. (2016). Addressing Differences Between Inbound and Outbound Agents for Effective Call Center Management. Global Business and Organizational Excellence, 36(1), 70-86. DOI:10.1002/joe.21757

Engel, J.F., Blackwell, R.D., \& Kollat, D.T. (1978). Consumer Behavior. Hinsdale, IL: Dryden Press.

Grbić, N., \& Puška, A. (2015). Utjecaj etnocentrizma na kupovno ponašanje potrošača na području Brčko distrikta BiH. Zbornik Ekonomskog fakulteta u Zagrebu, 13(2), 103-120. 
Hambrick, D.C., \& Mason, P.A. (1984). Upper Echelons: The Organization as a Reflection of Its Top Managers. The Academy of Management Review, 9(2), 193-206. DOI:10.2307/258434

Hines, J.M., Hungerford, H.R., \& Tomera, A.N. (1987). Analysis and synthesis of research on responsible environmental behaviour: A meta-analysis. Journal of Environmental Education 18(2), 1-8. DOI:10.1080/009589 64.1987.9943482

Hirschman, E.C. (1985). Cognitive processes in experimental consumer behavior. Research on Consumer Behavior, 1, 67-102.

Homburg, C., \& Giering, A. (2001). Personal characteristics as moderators of the relationship between customer satisfaction and loyalty-an empirical analysis. Psychology \& Marketing, 18(1), 43-66. DOI:10.1002/1520-6793

Iqbal, H.K., Ghafoor M.M., \& Shahbaz, S. (2013). Impact of Demographic Factors on Store Selection: An Insight in Pakistani Society. Journal of Marketing Management, 1(1), 34-45.

Jeyakumar, K., \& Paul Robert, T. (2010). Joint Determination of Price, Warranty Length and Production Quantity for New Products under Free Renewal Warranty Policy. International Journal for Quality Research, 4(1), 51-58.

Kacprzak, A., \& Pawłowska, A. (2017). Work and shopping overflow: Consequences and differentiation among selected psychological and demographic characteristics. European Management Journal, 35(6), 755-765. DOI:10.1016/j.emj.2017.06.003

Khaniwale, M. (2014). Consumer Buying Behavior. International Journal of Innovation and Scientific Research, 14(2), 278-286.

Kimberly, J.R., \& Evanisko, M.J. (1981). Organizational Innovation: The Influence of Individual, Organizational, and Contextual Factors on Hospital Adoption of Technological and Administrative Innovations. The Academy of Management Journal, 24(4), 689-713. DOI:10.5465/256170

Komal Prasad, R., \& Jha, M.K. (2014). Consumer buying decisions models: A descriptive study. International Journal of Innovation and Applied Studies, 6(3), 335-351.

Kos Koklič, M., \& Vida, I. (2009). A Strategic Household Purchase: Consumer House Buying Behavior. Managing Global Transitions, 7(1), 75-96.

Kotler, P., \& Armstrong, G. (2007). Principles of Marketing. Upper Saddle River, NJ: Prentice Hall.

Kozarević, S., \& Puška, A. (2015). Povezanost primjene lanca snabdijevanja, partnerskih odnosa i konkurentnosti malih i srednjih kompanija. Ekonomska misao i praksa, 10(2), 579-596.

Kurnoga Živadinović, N. (2004). Utvrđivanje osnovnih karakteristika proizvoda primjenom faktorske analize. Ekonomski pregled, 55(11-12), 952-966.

Liu, X., Wang, C., Shishime, T., \& Fujitsuka, T. (2012). Sustainable consumption: green purchasing behaviours of urban residents in China. Sustainable Development, 20(4), 293-308. DOI:10.1002/sd.484

Mainieri, T., Barnett, E.G., Valdero, T., Unipan, J., \& Oskamp, S. (1997). Green buying: the influence of environmental concern on consumer behavior. The Journal of Social Psychology, 137(2), 189-204. DOI:10. 1080/00224549709595430

Mansi, M., \& Pandey, R. (2016). Impact of demographic characteristics of procurement professionals on sustainable procurement practices: Evidence from Australia. Journal of Purchasing and Supply Management, 22(1), 31-40. DOI:10.1016/j.pursup.2015.06.001

Markovina, J., Kovačić, D., \& Radman, M. (2004). Uključenost pri donošenju kupovnih odluka - primjer tri prehrambena proizvoda. Journal of Central European Agriculture, 5(3), 151-159.

Mazloumi, S.S.S., Efteghar, A., Ghalandari, A., Saif, B., \& Aghandeh, I. (2013). Evaluating the effect of demographic differences on consumers' purchasing behavior (Case Study: Tetra Pak Consumers). International Research Journal of Applied and Basic Sciences, 4(7), 1866-1867.

Nordstroem, K., \& Ridderstrale, J. (2002). Funky business. Zagreb: Differo.

Olli, E., Grendstad, G., \& Wollebaek, D. (2001). Correlates of environmental behaviors: bringing back social context. Environment and Behavior, 33(2), 181-208. DOI:10.1177/0013916501332002 
Parment, A. (2013). Generation Y vs. Baby Boomers: Shopping behavior, buyer involvement and implications for retailing. Journal of Retailing and Consumer Services, 20(2), 189-199. DOI:10.1016/j.jretconser.2012.12.001

Peter, J.P. (2005). Consumer behavior and marketing strategy. Boston, MA: McGraw Hill.

Puška, A., Maksimović, A. \& Fazlić, S. (2015). Utjecaj kvalitetenazadovoljstvoilojalnoststudenata. Poslovnaizvrsnost. 9(2), 101-119.

Samdahl, D.M., \& Robertson, R. (1989). Social determinants of environmental concern: Specification and test of the model. Environment and Behavior, 21(1), 57-81. DOI:10.1177/0013916589211004

Sharma, K.C., \& Kaur, S. (2015). The Impact of Demographic Factors on Impulse Buying Behaviour of Online and Offline Consumers (A Case Study of Punjab, Haryana, New Delhi and Chandigarh). International Journal of Engineering Technology, Management and Applied Sciences, 3(9), 63-69.

Srivastava, M., \& Kaul, D. (2014). Social interaction, convenience and customer satisfaction: The mediating effect of customer experience. Journal of Retailing and Consumer Services, 26(6), 1028-1037. DOI:10.1016/j. jretconser.2014.04.007

Štulec, I., Petljak, K. \& Rakarić, J. (2017). Utjecaj demografskih karakteristika potrošača na proces donošenja odluke o kupovini. Ekonomska misao i praksa, 12(1), 381-404.

SueLin, C. (2010). Understanding Consumer Purchase Behavior in the Japanese Personal Grooming Sector. Journal of Yasar University, 17(5), 2821-2831.

Tam, J., \& Tai, S. (1998). The Psychographic Segmentation of the Female Market in Greater China. International Marketing Review, 15(1), 61-77. DOI:10.1108/02651339810205258

Tavakol, M., \& Dennick, R. (2011). Making sense of Cronbach's alpha. International Journal of Medical Education, 2, 53-55. DOI:10.5116/ijme.4dfb.8dfd

Tifferet, S., \& Herstein, R. (2012). Gender differences in brand commitment, impulse buying, and hedonic consumption. Journal of Product \& Brand Management, 21(3), 176-182. DOI:10.1108/10610421211228793

Waheed, A., Mahasan, S.S., \& Sandhu, M.A. (2014). Factor That Affects Consumer Buying Behavior: An Analysis of Some Selected Factors. Middle-East Journal of Scientific Research, 19(5), 636-641. DOI:10.5829/idosi. mejsr.2014.19.5.13623 


\section{UTICAJ DEMOGRAFSKIH KARAKTERISTIKA POTROŠAČA NA ODLUKE O KUPOVINI TEHNIČKIH PROIZVODA}

\section{Rezime:}

Izraz ponašanje potrošača postao je veoma popularan u novijim studijama. Odlikuju ga različiti procesi, pri čemu odluke potrošača o kupovini predstavljaju jedan od njih. Ovaj rad istražuje način na koji demografske karakteristike utiču na odluke o kupovini sa fokusom na tehničke proizvode, uključujući kućne aparate, računare, televizore i slične tehničke proizvode koji koštaju više od 400 KM. Empirijska studija sprovedena je u regionu severoistočne Bosne i Hercegovine, a 192 ispitanika uključeno je u studiju kako bi izrazile svoje navode o kupovnim odlukama. Analiza faktora korišćena je za identifikaciju šireg konstruktora kao osnove za posmatranje varijabli. Ukupno je identifikovano šest varijabli. Na osnovu izračunavanja Cronbachovih alfa indikatora, utvrđeno je da postoji niska interna afilijacija izjava u dve varijable, na osnovu čega su iste i odbačene. Stoga su četiri varijable korišćene za proučavanje odluke o kupovini.

Rezultati multivarijantne analize varijanse (MANOVA) pokazali su da pol, nivo prihoda i radni status ispitanika značajno utiču na odluke o kupovini kod potrošača. Analiza varijanse (ANOVA) je dalje pokazala da se žene ispod 25 godina i čiji su prihodi manji od $400 \mathrm{KM}$, uglavnom baveu odlukama o kupovini, tj. tome posvećuju najviše vremena Empirijski nalazi pokazuju da su najviše zadovoljni odlukama o kupovini muški ispitanici čiji se prihod kreće između 400 i $800 \mathrm{KM}$ i koji pripadaju kategoriji studenata mlađih od 25 godina.
Ključne reči:

ponašanje potrošača, odluke o kupovini, demografski faktori, analiza faktora, multivarijantna analiza varijanse, analiza varijanse. 